This item was submitted to Loughborough's Research Repository by the author.

Items in Figshare are protected by copyright, with all rights reserved, unless otherwise indicated.

\title{
Paving the road for flipped teaching in Spanish universities
}

PLEASE CITE THE PUBLISHED VERSION

http://doi.org/10.21125/inted.2017.1139

PUBLISHER

(C) IATED

VERSION

VoR (Version of Record)

\section{PUBLISHER STATEMENT}

This work is made available according to the conditions of the Creative Commons Attribution-NonCommercialNoDerivatives 4.0 International (CC BY-NC-ND 4.0) licence. Full details of this licence are available at: https://creativecommons.org/licenses/by-nc-nd/4.0/

\section{LICENCE}

CC BY-NC-ND 4.0

\section{REPOSITORY RECORD}

Gonzalez-Cruz, M. Carmen, Rosario Vinoles-Cebolla, Pablo Ballesteros-Perez, and Jose Luis FuentesBargues. 2019. "Paving the Road for Flipped Teaching in Spanish Universities". figshare.

https://hdl.handle.net/2134/32746. 


\title{
PAVING THE ROAD FOR FLIPPED TEACHING IN SPANISH UNIVERSITIES
}

\author{
M. Carmen González-Cruz ${ }^{1}$, Rosario Viñoles-Cebolla ${ }^{1}$, Pablo Ballesteros-Pérez ${ }^{2}$, \\ Jose Luis Fuentes-Bargues ${ }^{1}$ \\ ${ }^{1}$ Universitat Politècnica de València (SPAIN) \\ ${ }^{2}$ University of Reading (UNITED KINGDOM)
}

\begin{abstract}
Spanish university lecturers have traditionally spent most of their contact time with students explaining theory in the classroom. Once the theoretical contents have been presented, lecturers demonstrate (with little or no student participation) several reinforcing examples and practical exercises. Student involvement only occurs when they are asked to perform a series of tasks and exercises after the lesson and generally outside the classroom.
\end{abstract}

Active learning methodologies have been proven to significantly enhance the teaching-learning process, and fortunately, Spanish universities are increasingly promoting these approaches. Among these active learning methodologies, flip teaching is one of the most frequently adopted teaching strategies.

However, the introduction of flip teaching poses challenges and requires a radical change of mentality from lecturers and students. To succeed, participants must abandon former work habits and work on the theoretical concepts outside the classroom, while significantly increasing the degree of interaction inside and outside the classroom. Lecturers must spearhead this process of change, but success can only be achieved with student involvement.

This paper shows how flip teaching was implemented in a subject within the MSc in Project Management course at the Universitat Politècnica de València. Emphasis is given to active teaching strategy and the three basic components on which it relies: students, faculty, and the teachinglearning methodology. Results and conclusions extend the discussion and provides some guidelines on facilitating the (necessary) adoption of this and other active learning methodologies in Spanish universities.

Keywords: flipped classroom; educational innovation, active learning, teaching-learning process.

\section{INTRODUCTION}

In recent years, university processes inside and outside Spain have developed around best practices and quality models. Among the indicators for assessing the quality of a university is the academic performance of its students [1], [2]. The introduction of the European Higher Education Area (EHEA) has required universities to review their qualifications, training programmes, and how these programmes are taught. A new scenario has been established where students and their learning are placed at the centre of the teaching-learning process, and universities have had to rethink the educational model by promoting active methodologies.

Spanish university classes were traditionally taught using a methodology in which the lecturer is the most active participant and students passively listen for most of the time. These sessions are reinforced with the resolution of exercises and cases in which the lecturer offers further explanations and students practice the concepts studied in the theory lessons. Finally, students must demonstrate an understanding of the theoretical concepts and an ability to complete practical exercises in an examination that serves as a tool for teachers to evaluate student learning. However, these methodologies have evolved into other models, as shown in the Bologna Declaration, for example, where a credit system (ECTS - European Credit Transfer System) was established. The ECTS system is student-centred and sets the workload for students to achieve programme objectives.

Universities are exploring new ways to develop the process of teaching and learning [3]. The aim is for students to achieve better results in accordance with the effort made; and universities are rethinking their educational systems with respect to the student perception of the teaching and learning process [4] and the methodologies used [5]. 
It is necessary, therefore, to change the teaching and learning methodology in universities [6], [7]. For this reason, new curriculums have implemented more practical and less theoretical content, so that students play a more active role in the teaching-learning process. These approaches are known as active methodologies [8], [9]. The most important steps in this direction in recent years have been proposals for the implementation of flip-teaching in universities (e.g. [10], [11], [12], [13], [14], [15], [16]).

These changes in teaching methodology also imply an organisational change and key roles for the various players involved in this process.

This paper shows how the transformation of a traditional teaching methodology to flip teaching was made in a Spanish university - with an analysis of the role of faculty, students, and the university.

\section{BACKGROUND}

The European higher education system is configured as dynamic, flexible, and innovative. The various European systems are seeking to develop processes of student-centred learning and this involves reforming curriculums and teaching methodologies. In this scenario, it is necessary that the lecturer teaches the subject, while the students learn and demonstrate what they have learnt.

This model is described by Fernandez [17], who argues that teaching must move away from a system based on lecturers teaching and towards a model of students independently learning under the tutorship of lecturers. Fernandez proposes a new organisation of the teaching-learning process and highlights the importance in this new model of information and communication technologies and the possibilities they offer for developing new ways of learning. Other authors, such as Esteve and Gisbert [18], suggest that universities focus on students and offer active and practical education with new teaching methodologies that encourage active learning - and in which independent student work plays a key role [19].

Change in the European university system includes the availability of tools for collaborative work, especially e-learning tools. New technologies have contributed to the process of teaching and learning, and these tools reinforce the dynamics of work outside the classroom by enabling students and lecturers to maintain both individual and group communication during the course. The integration of these technologies in the process of university education is a reality, but further analysis and experimentation is needed.

In a review of teaching methods, De la Cruz [20] distinguishes three approaches or views for examining and analysing the relationship between teaching and learning. These models are: behaviourism; humanism; and the cognitive approach. The third approach currently dominates. This approach sees learning as an internal process by which the learner interacts with the environment. The cognitive approach emphasises the active and constructive aspects of learning and states that the fundamentals are: previously acquired knowledge; and the structuring of knowledge in increasingly complex schemes.

This theory revolves around the learner and sees the learner as an information processor. According to Ausubel [21], the level of prior knowledge that the learner brings to the learning situation is the most influential factor in learning exercises. Knowledge already acquired helps organise new information. When new information arrives in the mind of the learner, it is stored in the long-term memory and a 'filing system' is already in place. New information modifies the memory and produces a conceptual change. Learning is an assimilation and reconstruction of the information received [22].

In addition to previous knowledge, it is necessary to consider the personality variables and student motivation as determinants in the teaching-learning process. To favour a successful learning outcome, the lecturer needs an initial diagnosis of the existing knowledge of the students.

Importance is given in the cognitive approach to how knowledge is a social construction. Knowledge is a cultural product that is created, shared, transformed and transmitted. Hence, the importance of cooperative learning and teaching in groups [23].

Given the above and the structural changes in study plans (based on 12-week semesters for delivering the subject material), the amount of material that must be taught by the lecturer and learnt by the student makes the traditional university lecturing approach (complemented with examples and exercises and case studies to reinforce the concepts) difficult to implement. New technologies and 
methodologies - such as the 'reversed classroom' - enable a change in the educational model at universities.

These methodologies have been widely tested in secondary education (e.g. [24], [25], [26]) and are proposed as methodologies for future university education (e.g [11], [12], [13], [14], [15], [16], [27]).

The term 'flipped classroom' was defined by Bergmann and Sams [24] after they began distributing videotapes to students who had missed classes for various reasons (illness, etc.). After distributing the tapes, Bergmann and Sams realised that they could focus on the more individualised needs of their students.

Various versions of this model have emerged and are now termed 'reversed' [28], [29], [30].The F-L-I$\mathrm{P}$ scheme was offered by the Flipped Learning Network and Pearson School Achievement Services [31], [32], who summarised the four pillars of the methodology as: (F: flexible environment); (L: learning culture); (I: intentional content); and (P: professional educator). Finally, it is worth noting the contribution of Chen [33], who argued that rather than referring to FLIP we should refer to FLIPPED, incorporating three additional pillars in the methodology: ( $P$ : progressive networking activities); ( $E$ : engaging and effective learning experiences); (D: diversified and seamless learning platforms).

\section{METHODS}

The pedagogical model on which reverse methodology is based involves moving certain processes outside the classroom and then using class time (as well as teaching experience) to facilitate and enhance (theoretical and practical) teaching and learning. The student obtains and processes information outside the classroom, so that the time in the classroom with the lecturer (which is the most valuable time because it is so limited) is dedicated to a real interaction between lecturer and students to ensure a correct assimilation of the information. In this way, lecturers can add value to their role in the teaching-learning process with different techniques that promote active student learning [34].

Taking as a reference Bloom's Taxonomy [35], the lecturer should assign contents for study outside the classroom from the lowest levels of the taxonomy (comprehension and recall). Students can then take advantage of class-time to assimilate those contents linked to higher levels (create, evaluate, analyse, and implement) [36].

\section{HOW TO IMPLEMENT FLIP TEACHING METHODOLOGY IN UNIVERSITIES}

The successful implementation of the reverse methodology in a previously traditional teaching class depends on three pillars: context, faculty, and students.

\subsection{Context}

It is crucial to consider the type of subject in which the flip methodology is to be implemented: is the subject an undergraduate or master's degree; is it a core subject (obligatory for all students) or optional (as a specialty or additional training); how many students are enrolled [13] (because implementing a large group can be difficult, but not impossible); the course and the semester in which it is taught; the time slot scheduled for the classes; whether or not students have easy access to the tools and resources needed to facilitate the development of the methodology; and is the implementation imposed from above or was it a voluntary decision by teachers. In addition, considering that Spanish universities are increasingly incorporating this type of methodology in the curriculum, it is necessary to know if the university offers support (training, manuals, etc.) or has created an associated educational project. Such a pilot project was launched in 2014 by the Universitat Politècnica de València, and the project has become increasing large. All these aspects help shape the context in which the change is made and may help determine the degree of success.

\subsection{Faculty}

This type of teaching is more complex than traditional teaching. The lecturer ceases to be a mere presenter of information and evaluator of assimilation. During class, the lecturer must lead, guide, observe, and evaluate students by providing relevant feedback when needed. The lecturer's role as assessor also becomes more difficult because he or she must perform additional monitoring and assessment and offer more formative feedback to students [29]. The lecturer will also have a decisive 
role in determining what should be taught and what should be studied by students [13]. For this reason, faculty must possess or acquire the knowledge to understand the methodologies and tools that encourage student effort and learning. Lecturers must make a personal commitment to student learning and this will mean more hours of work (especially during the first year of the new methodology). Lecturers will also need to develop the technological and educational skills needed for the transmission of information outside the classroom (meaning the preparation of material for students to work at home - such as videos, digital documents, and web links) and the material needed for reviewing student work (such as practical exercises and questionnaires). This means learning to use technological and educational resources that facilitate these tasks and so increasing the effectiveness of presentations [37]. In this type of reverse methodology, it is essential that lecturers conscientiously plan their own and student activities before, during, and after classes.

\subsection{Students}

The third pillar for change are the students. Change is centred on planning, motivation, and active and independent learning.

- A suitable organisation of teaching and the necessary methods and materials enables students to correctly plan their activities and so avoid possible overloads [12]. Such planning enables students to have an overall view of the effort needed in the classroom and at home: and this ability is linked to increased motivation and involvement. This is especially important at university level because many students combine studies with paid work or family obligations (especially in master's courses).

- Student motivation should link the classroom and the home [15]. The most important motivation for the classroom is attendance. This is critical because class tasks require more interaction and participation with peers, and more personalised advice from the lecturer [12]. A method for ensuring motivation in the classroom is by assessing the work and the contributions that students make in the classroom and re-thinking the interaction based on the difficulties and needs experienced. Motivation at home is more difficult to control because the lecturer is not face-to-face with the student. For this reason, it is important to respond to the urgent and important questions that arise as quickly as possible (email, web platform, etc.), as well as rewarding the work done at home and demonstrating to everybody that those working effectively at home understand, learn, and achieve better results.

- Under the traditional methodology, the student usually spends most class time listening passively to the lecturer. However, it is now necessary to make learning independent and active [11]. The student must be prepared to perform - usually alone - considerable work outside the classroom in tasks such as watching videos, reading, or searching for information. In this way, the student arrives in class with the material already understood and is ready to share information and resolve tasks designed to help consolidate the learning.

\section{RESULTS}

Below is an example of how the transformation for the 2015-2016 course entitled 'Project Scheduling with MS Project' in the UPV Master in Management and Project Management course was prepared at the UPV School of Industrial Engineering. It had been observed in recent years that students studying the subject were largely passive. They simply listened to the explanation of the software (repeating steps that were forgotten before the next class) and rarely participated (only 2-3 students playing an active role in class). Therefore, the aim in transforming the class was to ensure that students became motivated and wanted to learn and participate.

The context that conditioned the transformation was [38]:

- The subject lecturers voluntarily decided to participate in the project - which began during the 2014-2015 course.

- This was a core subject that must be taken by all students enrolled in the second semester of the first year of the master's course and had been allocated 2.5 ECTS credits.

- Students on the course were varied and came from a variety of different degrees (including industrial engineering, architecture, and civil engineering); some were also studying other courses and some joined a little late in the year because they came from abroad. 
- The group size was 26 students and this enabled the lecturers to closely control the classes.

- The only handicap was that the delivery of the classes was very intensive. Some 25 hours of class were scheduled in less than one month.

There was only one lecturer with extensive knowledge and experience in teaching the subject. This situation had its advantages and disadvantages: the main advantage was that no coordination was needed with colleagues and the lecturer could adapt the pace of classes and make changes without difficulty. The main drawback was that the lecturer had to assume the entire workload involved in making the changes. The main transformation for the lecturer was centred on acquiring teaching knowledge (attending training courses and workshops given by the UPV Institute of Educational Sciences) to better understand the methodologies and tools that encourage student effort and learning. The lecturer had to make a personal commitment to student learning and this meant an increased workload (planning and preparation of material, course guide, videos, and exercises) and preparation on the UPV-learning platform (PoliformaT).

All the enrolled students attended a meeting two months before the start of the course and were informed about the learning objectives of the subject and the reverse methodology that would be followed in class. At that first meeting, students were shown what was expected from them, both at home and in the classroom, and the learning value of the reversed class methodology. Their motivation was stimulated by asking about their existing knowledge, interests, and so on.

\section{CONCLUSIONS}

Changing the teaching methodology to the reverse class approach affects faculty and requires considerable planning of resources and materials - and unlike the traditional teaching approach - it also requires a considerable effort in the monitoring and control of the work done by students outside the classroom. This latter requirement requires teachers to analyse what aspects they wish to assess, as well as when, how, and using which tools.

For the student, such a change in working methods means more independence outside the classroom. That is why considerable motivation is required. A high level of motivation may be present from the beginning and the lecturer will be an important factor in ensuring that such motivation continues. But if there is no initial motivation from the student, then the lecturer will have to make an effort to capture their interest.

Finally, it has been seen that context is a conditioning factor. Universities often impose several aspects of this context (such as group size, class schedules, and the teaching semester), but other aspects of the context are often decisions made by faculty (such as the availability of tools or resources for the development of the methodology). In some universities, resources that are very useful in the preparation for the transformation of methodology are easily accessible, but these resources are sometimes missing in other universities.

In short, the process of changing the teaching of a subject from a traditional approach to a flip methodology must carefully consider the characteristics of the three pillars that support teaching and give each equal importance.

\section{REFERENCES}

[1] J. Cortadellas, Información para la toma de decisiones: indicadores internos e indicadores externos, Cinda, Colección Gestión Universitaria, 2002.

[2] I. G. López, "Dimensiones de evaluación de la calidad universitaria en el Espacio Europeo de Educación Superior," Revista electrónica de investigación psicoeducativa, vol. 10, pp. 445-468, 2006

[3] F. Gutiérrez-Solana, "Políticas universitarias para una nueva década: problemas y oportunidades," La Cuestión Universitaria, vol. 6, pp. 4-11, 2016.

[4] R. Rocha, "Escala de Opinión de los Estudiantes sobre la Efectividad de la Docencia (EOEED) en Educación Superior," Formación universitaria, vol. 6, pp. 13-22, 2013.

[5] C. Rodríguez and V. Castillo, "Quality in initial teacher training: the deficiencies in pedagogical and disciplinary skills in Chile," Actualidades Investigativas en Educación, vol. 14, pp. 373-399, 2014. 
[6] F. S. González, "Evolución y desarrollo de un Entorno Personal de Aprendizaje en la Universidad de León," Digital Education Review, vol. 18, pp. 48-66, 2010.

[7] M. A. Zabalza, "Metodología docente," REDU, Revista De Docencia Universitaria, vol. 9, pp. 7598, 2011.

[8] A. Ribes, Metodologías Activas, Valencia, Editorial de la Universitat Politècnica de València, 2008.

[9] F. López, Metodología participativa en la enseñanza universitaria, Narcea Ediciones, 2005.

[10] S. See, and J. M. Conry, "Flip My Class! A faculty development demonstration of a flippedclassroom," Currents in Pharmacy Teaching and Learning, vol. 6, pp. 585-588, 2014.

[11] T. W. Teo, K. C. D. Tan, Y. K. Yan, Y. C. Teo, and L. W. Yeo, "How flip teaching supports undergraduate chemistry laboratory learning," Chemistry Education Research and Practice, vol. 15, pp. 550-567, 2014

[12] E. Argente, A. Espinosa, and A. García-Fornes, "Experiencia de la aplicación de la metodología Flipped-Teaching en la asignatura de Concurrencia y Sistemas Distribuidos," in Congreso InRed 2015, Universitat Politècnica de València, http://dx.doi.org/10.4995/INRED2015.2015, 2015.

[13] J. J. Vázquez, and E. P. Chiang, "Flipping out! A case study on how to flip the principles of economics classroom," International Atlantic Economic Society, vol. 21, pp. 379-390, 2015.

[14] A. El-Mowafy, M. Kuhn, and T. Snow, "Blended learning in higher education: Current and future challenges in surveying education," Issues in Educational Research, vol. 23, pp.132-150, 2013.

[15] A. Fidalgo-Blanco, M. Martinez-Nuñez, and O. Borrás-Gene, "Micro flip teaching - An innovate model to promote the active involvement of students," Computers in Human Behavior, http://dx.doi.org/10.1016/j.chb.2016.07.060, 2016.

[16] E. Sengel, "To FLIP or not to FLIP: Comparative case study in higher education in Turkey," Computers in Human Behavior, vol. 64, pp. 547-555, 2016.

[17] M. Fernández Enguita, "La profesión docente: realidades y retóricas," in Conferencia impartida en la XXV Semana Monográfica Enseñar y aprender: ideas y prácticas del profesorado, 2009.

[18] F. M. Esteve, and M. Gisbert, "El nuevo paradigma de aprendizaje y nuevas tecnologías," REDU, Revista de Docencia Universitaria, vol. 9, pp. 55-73, 2011.

[19] Rué Domingo, J. (2009). El aprendizaje autónomo en la universidad. Madrid: Narcea.

[20] A. De la Cruz, "Documentación del Taller de Elaboración del Proyecto Docente," Instituto de Ciencias de la Educación ICE, Universidad Politécnica de Valencia, 1996.

[21] D. P. Ausubel, J. D. Novak, and H. Hanesian, Psicología educativa: un punto de vista cognoscitivo, México: Trillas, 1976.

[22] L. B. Resnick, and L. E. Klopfer, "Toward the Thinking Curriculum: Current Cognitive Research," in 1989 ASCD Yearbook. Association for Supervision and Curriculum Development, 1989.

[23] R. E. Slavin, Cooperative Learning, Prentice-Hall. New Jersey, 1990.

[24] J. Bergmann, and A. Sams, "Remixing Chemistry Class: Two Colorado Teachers Make Vodcasts of Their Lectures to Free Up Class Time for Hands-On Activities," Learning \& Leading with Technology, vol. 36, pp. 22-27, 2009.

[25] D. Schultz, S. Duffield, S. C. Rasmussen, and J. Wageman, "Effects of the Flipped Classroom Model on Student Performance for Advanced Placement High School Chemistry Students," Journal of Chemical Education, vol 91, pp. 1334-1339, 2014

[26] S. C. Kong, "An experience of a three-year study on the development of critical thinking skills in flipped secondary classrooms with pedagogical and technological support," Computers \& Education, vol. 89, pp. 16-31, 2015.

[27] T. N. Jones, "160 A comparison of traditional versus flip-class teaching methods on student satisfaction and assessment," Journal of Equine Veterinary Science, vol. 35, pp. 451-452, 2015. 
[28] J. Gerstein, The flipped clasrrom model A full picture, Mensaje publicado en https://usergeneratededucation.wordpress.com/2011/06/13/the-flipped-classroommodel-a-fullpicture/, 2011.

[29] J. Bergmann, and A. Sams, Flip your classroom: Reach every student in every class every day. Washington, DC: Internal Society for Techonology in Education, 2012.

[30] H. Staker, and M. Horn, Classifying K-12 blended learning, Innosight Institute: http://files.eric.ed.gov/fulltext/ED535180.pdf, 2012.

[31] N. Hamdan, P. McKmnight, K. McKnight, and K. Arfstrom, The flipped learning model: A white paper based on the literature review, Flipped Learning Network:

http://researchnetwork.pearson.com/wpcontent/uploads/WhitePaper_2014_FlippedLearning_vFi nal_CB_WEB.pdf, 2013.

[32] N. Hamdan, P. McKmnight, K. McKnight, and K. Arfstrom, A review of flipped learning, Flipped Learning Network: http://flippedlearning.org/wp-content/uploads/2016/07/Extension-of-FLippedLearning-LIt-Review-June-2014.pdf, 2013.

[33] Y. Chen, Y. Wang, Kinshuk, N.S. Chen, "Is FLIP enough? Or should we use the FLIPPED model instead?," Computers \& Education, vol. 79, pp.16-27, 2014.

[34] S. Luján-Mora, "De la clase magistral tradicional al MOOC: doce años de evolución de una asignatura sobre programación de aplicaciones web," Revista de Docencia Universitaria, vol. 11, pp. 279-300, 2013.

[35] B. S. Bloom, M. D. Engelhart, E. J. Furst, W. H. Hill, and D. R. Krathwohl, Taxonomy of educational objectives: The classification of educational goals Handbook I: Cognitive domain, New York: David McKay Company, 1956.

[36] D. R. Krathwohl, "A revision of Bloom's taxonomy: An overview," Theory Into Practice, vol. 41, pp. 212-218, doi:10.1207/s15430421tip4104_2, 2002.

[37] T. Zhu, and L. Zhang, "Flip classroom design and implementation of the literature retrieval course network teaching platform," in The 10th International Conference on Computer Science \& Education (ICCSE 2015), Fitzwilliam College, Cambridge University, UK, July 22-24, 2015.

[38] R. Viñoles-Cebolla, M. J. Bastante-Ceca and J. L. Fuentes-Bargues, "Experiencia piloto en la implantación de la metodología docente "clase invertida" en una asignatura de programación de proyectos", in The 20th International Congress on Project Management and Engineering (CIDIP 2016), Technical University of Cartagena, Murcia, July 13-15, pp. 2442-2454, 2016. 